\title{
ANALISIS SISTEM PERHITUNGAN DAN PELAPORAN PAJAK PENGHASILAN KARYAWAN DI KANTOR KESYHABANDARAN DAN OTORITAS PELABUHAN KELAS I BITUNG
}

\author{
Nosevira H. K. Rumondor ${ }^{1}$, Lintje Kalangi ${ }^{2}$, Dhullo Afandy ${ }^{3}$ \\ ${ }^{1,2,3}$ Fakultas Ekonomi dan Bisnis, Jurusan Akuntansi, Universitas Sam Ratulangi, Jl. Kampus Bahu, Manado, \\ 95115, Indonesia \\ E-mail : nosevirakesita07@gmail.com
}

\begin{abstract}
Income tax article 21 is the tax applicable for employee. The income of the employee is subject to withholding of Income Tax Article 21, for the company is authorized to withhold the employee's income. The purpose of this study is to analyze whether the system of calculation and reporting Income Tax Article 21 has been in accordance with the taxation law and regulation. The research method used is descriptive qualitative method. The results obtained are based on the provision of Object of Income Ta Article 21 according to DGT Regulation PER-16 / PJ / 2016, there is still object of Income Tax Article 21 which has not been collected by the Office of Kesyahbandaran dan Otoritas Pelabuhan Kelas 1 Bitung. In terms of calculations are in accordance with the the Regulation of the Director General of Tax No. PER-16 / PJ? 2016. For the calculation of final Income Tax Article 21 are based on Ministry of Finance (MoC) Decree PMK 262 in 2010 for the calculation of Article 21 tax for permanent employees who become the burden state budget. In terms of reporting of Periodic Tax Return, conducted by the State Treasury Office (KPN) through e-filling application on the website of the Directorate General of Taxes and has been in accordance with applicable provisions.
\end{abstract}

Keywords : Income Tax Article 21, employee.

\section{PENDAHULUAN}

Pajak menurut Pasal 1 ayat (1) Undang-undang Nomor 28 Tahun 2007 tentang Ketentuan Umum dan Tata Cara Perpajakan adalah "Pajak adalah kontribusi wajib kepada Negara yang terutang oleh orang pribadi, atau badan yang bersifat memaksa berdasarkan undang-undang, dengan tidak mendapatkan imbalan secara langsung dan digunakan untuk keperluan Negara bagi sebesar-besarnya kemakmuran rakyat".

Menurut Gunadi (2012:55) Pemotongan pajak pada sumbernya merupakan cara yang paling efisien untuk menghasilkan penerimaan negara. Dengan pemotong yang relatif dan secara administratif tertib dapat diperoleh penerimaan segera yang meliputi sejumlah besar wajib pajak orang pribadi dan sekaligus sosialisasi kewajiban pajak ke seluruh masyarakat.Penerimaan Pajak di Indonesia dibagi dua jenis, yaitu Pajak Pusat dan Pajak Daerah. Pajak Pusat yaitu Pajak Penghasilan (PPh), Pajak Pertambahan Nilai dan Pajak Penjualan atas Barang Mewah (PPN dan PPnBM), dan Pajak Bumi dan Bangunan (PBB), Bea Materai, Bea Masuk dan Cukai. Pajak Penghasilan Pasal 21 adalah pajak atas penghasilan berupa gaji, upah, honorarium, tunjangan, dan pembayaran lain dengan nama dan dalam bentuk apapun sehubungan dengan pekerjaan atau jabatan, jasa, dan kegiatan yang dilakukan oleh orang pribadi Subjek Pajak dalam negeri, sebagaimana dimaksud dalam Pasal 21 Undang-Undang No.36 Tahun 2008 Tentang Pajak Penghasilan. Dan apabila orang pribadi Subjek Pajak dalam negeri memperoleh penghasilan dan dikenakan PPh Pasal 21, maka menjadi wajib

pajak orang pribadi dalam negeri. 
Pajak penghasilan merupakan pajak yang dipungut pada obyek pajak atas penghasilannya. Pajak penghasilan akan selalu dikenakan terhadap orang atau badan usaha yang memperoleh penghasilan di Indonesia. Pajak yang berlaku bagi pegawai/karyawan adalah pajak penghasilan pasal 21. Wajib Pajak diharapkan mampu menghitung sendiri jumlah pajak yang terutang, membayar dan melaporkan sendiri jumlah kewajiban perpajakannya. Hal ini dapat terlaksana dengan baik apabila wajib pajak memahami peraturan perpajakan dan mengikuti aturan yang sesuai dengan undang-undang perpajakan. Jika tidak dapat terlaksana dengan baik, dalam artian tidak mengikuti aturan yang sudah berlaku bisa terjadi kesalahan yang dapat merugikan bagi pemerintah maupun bagi Wajib Pajak itu sendiri. Untuk menghindari kecurangan yang dilakukan oleh Wajib Pajak, ketika Wajib Pajak mendapatkan penghasilan ada baiknya jika penghasilan tersebut dipotong pajak terlebih dahulu.

\section{TINJAUAN PUSTAKA}

\subsection{Subjek Pajak dan Wajib Pajak}

Subjek Pajak menurut Mardiasmo (2016) adalah:

1. a. Orang pribadi;

2. Bentuk Usaha Tetap (BUT). Subjek Pajak dapat dibedakan menjadi:

1. Subjek Pajak dalam negeri

a. Subjek pajak orang pribadi

b. Subjek Pajak badan

c. Subjek Pajak warisan

2. Subjek Pajak luar negeri

\subsection{Objek PPh Pasal 21 Bagi Bukan Pegawai}

Menurut Peraturan Direktur Jenderal Pajak Nomor PER-16/PJ/2016 dalam pasal 1 ayat (12) Penerima penghasilan Bukan Pegawai adalah orang pribadi selain Pegawai Tetap dan Pegawai Tidak Tetap/Tenaga Kerja Lepas yang memperoleh penghasilan dengan nama dan dalam bentuk apapun dari Pemotong PPh Pasal 21 dan/atau PPh Pasal 26 sebagai imbalan jasa yang dilakukan berdasarkan perintah atau permintaan dari pemberi penghasilan

\subsection{Tidak Termasuk Objek Pajak Penghasilan Pasal 21}

Berdasarkan Undang-Undang Nomor 36 tahun 2008, yang bukan termasuk objek pajak penghasilan pasal 21 adalah:

1. Penerimaan dalam bentuk natura dan/atau kenikmatan dalam bentuk apapun yang diberikan oleh Wajib Pajak atau Pemerintah, kecuali diberikan oleh bukan Wajib Pajak, Wajib Pajak yang dikenakan Pajak Penghasilan yang

2. Beasiswa yang diterima atau diperoleh Warga Negara Indonesia dari Wajib Pajak pemberi beasiswa dalam rangka mengikuti pendidikan formal/nonformal yang terstruktur baik di dalam negeri maupun luar negeri.

\subsection{Dasar Pengenaan Pajak dan Cara Menghitung Penghasilan Kena Pajak}

\subsubsection{Dasar Pengenaan Pajak}

Mardiasmo (2016) menjelaskan untuk Wajib Pajak dalam negeri dan Bentuk Usaha

Tetap (BUT) yang menjadi dasar pengenaan pajak adalah Penghasilan Kena Pajak. Sedangkan untuk Wajib Pajak luar negeri adalah penghasilan bruto.

\subsubsection{Cara Menghitung Penghasilan Kena Pajak}

Penghitungan besarnya Penghasilan Netto bagi Wajib Pajak dalam negeri dan bentuk usaha tetap dapat dilakukan dengan dua cara, yaitu:

1. Menggunakan pembukuan.

2. Menggunakna Norma Penghitungan Penghasilan Netto. 


\subsection{Jenis-Jensi Pajak Penghasilan}

Terdapat beberapa jenis Pajak Penghasilan menurut Siti (2016), yaitu:

1. Pajak Penghasilan Pasal 21/26

$\mathrm{PPh}$ Pasal 21 adalah pajak atas penghasilan berupa gaji, upah, honorarium, tunjangan, dan pembayaran lain dengan nama dan dalam bentuk apa pun sehubungan dengan pekerjaan atau jabatan, jasa, dan kegiatna yang dilakukan oleh orang pribadi Subjek Pajak dalam negeri, sebagaimana dimaksud dalam Pasal 21 Undang-Undang Pajak Penghasilan.

$\mathrm{PPh}$ Pasal 26, adalah pajak atas penghasilan berupa gaji, upah, honorarium, tunjangan, dan pembayaran lain dengan nama dan dalam bentuk apa pun sehubungan dengan pekerjaan atau jabatan, jasa, dan kegiatna yang dilakukan oleh orang pribadi Subjek Pajak dalam negeri, sebagaimana dimaksud dalam Pasal 26 Undang-Undang Pajak Penghasilan.

2. Pajak Penghasilan Pasal 22

Merupakan pembayaran Pajak Pengahasilan dalam tahun berjalan yang dipungut oleh:!

a. Bendahara pemerintah, termasuk bendahara pada Pemerintah Pusat, Pemerintah Daerah, instansi atau lembaga pemerintah, dan lembaga-lembaga negara lainnya, berkatian dengan pembayaran atas penyerahan barang, termasuk juga dalam pengertian bendahara adalah pemegang kas dan pejabat lain yang menjalankan fungsi yang sama;

b. Badan-badan tertentu, baik badan pemerintah maupun swasta, berkenaan dengan kegiatan di bidang impor atau kegiatan usaha di bidang lain seperti kegiatan usaha produksi barang tertentu antara lain otomotif dan semen; dan

c. Wajib pajak badan tertentuuntuk memungut

3. Pajak Penghasilan Pasal 24

Ketentuan pasal $24 \mathrm{UU} \mathrm{PPh}$ mengatur tentang perhitungan besarnya pajak atas penghasilan yang dibayar atau terutang di luar negeri yang dapat dikreditan terhadap pajak penghasilan yang terutang atas seluruh penghasilan Wajib Pajak dalam negeri. Pengkreditan pajak luar negeri dilakukan dalam tahun digabungkannya penghasilan dari luar negeri dengan penghasilan di Indonesia.

4. Pajak Penghasilan Pasal 25

Ketentuan pasal 25 Undang-Undang Pajak Penghasilan mengtur tentang penghitungan besarnya angsuran bulanan yang harus dibayar sendiri oleh Wajib Pajak dalam tahun berjalan.

\subsection{Penelitian Terdahulu}

Mangasi Sinurat tahun 2013 dengan judul Perhitungan dan Pemotongan Pajak

Penghasilan (PPh) Pasal 21 atas Pegawai Tetap pada PT. PLN (Persero) Cabang Medan. Hasil penelitian Perhitungan dan pemotongan Pajak Penghasilan (PPh) Pasal 21 pada PT. PLN (Persero) Cabang Medan telah sesuai dengan Undang - Undang Pajak No. 36 Tahun 2008.

Wilda Fitria tahun 2015 dengan judul Analisis Penghitungan Pemotongan, Penggajian Karyawan Terhadap Pajak Penghasilan Pasal 21 (PPh 21) Pada Perusahaan Farmasi (Studi

Kasus di PT.Brataco Chemika Malang). Hasil penelitian Berdasarkan pembahasan perusahaan telahmelakukan perhitungan dan pemotongan PPh Pasal 21 dengan benar, namun dalam perhitungannya dilakukan oleh perusahaan tidak sesuai dengan peraturan perpajakan yang berlaku. Kesalahannya ada pada pengurangan yang dilakukan oleh perusahaan. Sehingga hasil yang diperoleh perusahaan tidak di sesuai dengan hasil analisis berdasarkan Undang-Undang Perpajakan. 


\section{METODE PENELITIAN}

\subsection{Jenis Penelitian}

Penelitian ini pun dapat disebut penelitian deskriptif jika dilihat dari klasifikasi penelitian berdasarkan tingkat eksplanasi. Penelitan deskriptif yaitu penelitian yang dilakukan untuk mengetahui nilai masing-masing variabel, baik satu variabel atau lebih sifatnya independen tanpa membuat hubungan maupun perbandingan dengan variabel yang lain.

\subsection{Tempat dan Waktu Penelitian}

Penelitian berjudul Analisis Sistem Perhitungan dan Pelaporan Pajak Penghasilan Karyawan Di Kantor Keshabandaran dan Otoritas Pelabuhan Kelas 1 Bitung ini dilakukan di Kantor Keshabandaran dan Otooritas Pelabuhan Kelas 1 Bitung. Penelitian ini dimulai pada bulan Juni 2017 sampai bulan Agustus 2017.

\subsection{Prosedur Penelitian}

1. latar belakang

2. Rumusan masalah

3. Tujuan Penelitian

4. Pengumpulan Data

5. Mengumpulkan data yang berhubungan dengan judul skripsi terdiri dari
a.
Data Sekunder

b. Data Primer

6. Memperoleh gambaran umum dari objek penelitian secara keseluruhan serta mengetahui permasalahan yang ada.

7. Mengolah data yang ada

8. Memberikan kesimpulan dan memberikan saran.

\subsection{Metode Pengumpulan Data}

\subsubsection{Jenis Data}

Jenis data yang digunakan dalam penelitian ini adalah jenis data kuantatif. Data kuantitatif yang diteliti yaitu data daftar gaji dan SPT PPh Pasal 21 tahun 2016 karyawan di Kantor Keshabandaran dan Otooritas Pelabuhan Kelas 1 Bitung.

\subsubsection{Sumber Data}

Sumber data dalam penelitian ini adalah data primer berupa hasil wawancara dengan pimpinan serta pegawai Kantor Keshabandaran dan Otoritas Pelabuhan Kelas 1 Bitung dan data sekunder yaitu berasal dari daftar gaji dan SPT Tahunan PPh Pasal 21 Karyawan tahun 2016.

\subsubsection{Teknik Pengumpulan Data}

\section{Pengumpulan Data}

Dalam hal ini peneliti akan mengumpulkan data-data dari kantor Kesyhabandaraan dan

Otoritas Pelabuhan Bitung yang di perlukan untuk proses penelitian yang terkait dengan permasalahan. Data-data yang terkumpul diperoleh melalui prosedur yaitu survei pendahuluan hal ini di lakukan untuk mengetahui keadaan dari organisasi secara keseluruhan sehingga dapat menentukan masalah apa yang dihadapi. Survei dilakukan dengan cara sebagai berikut :
a. Interview
b. Dicumenter

2. Menganalisis data

3. Menginprestasikan Data

4. Kesimpulan

\subsection{Metode Analisis}

1. Mengumpulkan dan mempelajari dokumen-dokumen yang digunakan dalam penghitungan Pajak Pengahasilan Pasal 21. 
2. Mempelajari prosedur-prosedur yang dilakukan dalam penghitungan, atas Pajak Penghasilan Pasal 21.

3. Menganalisa dan membandingkan perhitungan Pajak Penghasilan Pasal 21 karyawan menurut Kantor sesuai atau tidak dengan ketetapan Undang-Undang Perpajakan yang terkait.

4. Menguji perhitungan laporan selama bulan Januari-Desember 2016 dan Januari-April 2017

5. Mengidentifikasi objek pajak.

\section{HASIL ANALISIS DAN PEMBAHASAN}

4.1 Hasil Penelitian

4.1.1 Perhitungan PPh Pasal 21 Bagi Pegawai Tetap yang Menjadi Beban APBN

Berikut ini merupakan perhitungan PPh Pasal 21 atas honor yang dibuat oleh Kantor Kesyahbandaran dan Otoritas Pelabuhan Kelas 1 Bitung :

1. Pejabat Pengadaan Barang/Jasa dan Panitia Pemeriksa/Penerima Pengadaan Barang/Jasa.

2. Pegawai Pelaksana Pengelolaan Sistem Akuntansi Pemerintah Tingkat Wilayah, dan

3. Petugas Pengelola PNBP (Penerimaan Negara Bukan Pajak), Jasa Kenavigasian, Perkapalan dan Kepelabuhan.

\subsubsection{Perhitungan PPh Pasal 21 Pada Bagi Bukan Pegawai}

Kantor Kesyhabandaran dan Otoritas Pelabuhan kelas I Bitung juga membayarkan fee atas jasa servis AC, Komputer dan pemeliharaan gedung kantor.

\subsubsection{Pemotongan dan Penyetoran PPh Pasal 21}

Pemotongan PPh Pasal 21 pegawai Kantor Kesyhabandaran dan Otoritas Pelabuhan Kelas I Bitung dilakukan oleh KPPN dengan memotong langsung pajak penghasilan pasal 21 pada penghasilan pegawai masing-masing.PPh yang dipotong tersebut disetor ke Kantor Perbendaharaan Negara (KPN) Provinsi Sulawesi Utara yang kemudian akan disetor ke rekening Direktorat Jenderal Pajak.

\subsubsection{Pelaporan PPh Pasal 21}

SSP elektronik yang telah disetor kemudian akan dilaporkan oleh KPN di website Direktorat Jenderal Pajak dalam bentuk Comma Separated Value(CSV). CSV dibuat dengan cara sebagai berikut :

1. Log in pada aplikasi e-SPT dengan menggunakan NPWP dan password.

2. Membuat data baru sesuai bulan pajak terutang.

3. Mengisi data SPT yang didalamnya memuat data Daftar Pemotongan Pajak, SPT Induk dan Daftar SSP/Pbk.

4. Setelah semua data tersimpan, maka dibuat file CSV untuk dilaporkan melalui website DJP online dan file PDF untuk dicetak dan diarsipkan.

Setelah KPN membuat CSV SPT PPh Pasal 21 kemudian KPN melaporkan CSV tersebut pada website DJP online pada tanggal 20 bulan berikutnya, dengan cara sebagai berikut:

1. Log in pada website DJP Online menggunakan NPWP dan Password;

2. Memilih menu e-filling dan mengunggah file CSV SPT yang telah dibuat kepada DJP untuk diverifikasi ;

3. Mendapatkan kode verifikasi melaui email;

4. Mongkonfirmasi kode verifikasi yang telah diterima untuk mengirim file CSV SPT yang akan dilapor:

5. File CSV telah berhasil dilaporkan dan kantor Kesyahbandaran dan Otoritas Pelabuhan kelas 1 Bitung menerima Bukti Penerimaan Elektronik (BPE); 
Setelah menerima BPE, kantor Kesyahbandaran dan Otoritas Pelabuhan kelas 1 Bitung mencetak BPE tersebut dan melampirkannya pada SPT yang telah dicetak dan kemudian mengarsipnya.

\subsection{Pembahasan}

\subsubsection{Objek PPh Pasal 21}

Berdasarkan hasil penelitian pada bagian sebelumnya di sesi bahwa, objek PPh Pasal 21 yang ada di Kantor Kesyahbandaran dan Otoritas Pelabuhan kelas 1 Bitung dari segi operasional yaitu penghasilan yang diterima pegawai berupa:

1. Penghasilan yang bersifat teratur yang diterima secara bulanan, yaitu gaji pegawai dan tunjangan-tunjangan lainnya. Tunjangan-tunjangan tersebut antara lain tunjangan istri, tunjangan anak, tunjangan struktural/fungsional, tunjangan beras, tunjangan khusus dan tunjangan lain-lain.

2. Kantor Kesyhabandaran dan Otoritas Pelabuhan kelas I Bitung juga menerapkan pembayaran penghasilan yang bersifat tidak teratur seperti THR dan uang lembur. Uang lembur dihitung berdasarkan jumlah jam kerja yaitu Rp 30.000,- per jam.

Kantor Kesyhabandaran dan Otoritas Pelabuhan kelas I Bitung juga membayarkan honor bagi

1. Pejabat Pengadaan Barang/Jasa dan Panitia Pemeriksa/Penerima Pengadaan Barang/Jasa bagi pegawai tertentu yang telah ditetapkan.

2. Pegawai Pelaksana Pengelolaan Sistem Akuntansi Pemerintah Tingkat Wilayah, dan

3. Petugas Pengelola PNBP (Penerimaan Negara Bukan Pajak), Jasa Kenavigasian, Perkapalan dan Kepelabuhan.

\subsubsection{Perhitungan PPh Pasal 21 Karyawan}

Untuk menghitung PPh Pasal 21 atas penghasilan pegawai tetap, terlebih dahulu

dihitung seluruh penghasilan bruto yang diterima atau diperoleh selama sebulan, yang meliputi gaji, segala jenis tunjangan dan pembayaran teratur lainnya, termasuk uang lembur dan pembayaran sejenisnya. Kantor Kesyahbandaran dan Otoritas Pelabuhan Kelas 1 Bitung dalam menghitung PPh Pasal 21 terlebih dahulu

menghitung seluruh penghasilan bruto yang diterima atau diperoleh selama sebulaan yang meliputi gaji, tunjangan umum, tunjangan khusus beras, tunjangan jabatan struktural atau fungsional dan tunjangan khusus pajak.

\subsubsection{Perhitungan PPh Pasal 21 Bagi Pegawai Tetap}

Kantor Kesyahbandaran dan Otoritas Pelabuhan Kelas 1 Bitung melakukan perhitungan PPh Pasal 21 dengan menggunakan pedoman Peraturan Direktur Jenderal Pajak No. PER-16/PJ/2016. Perhitungan PPh Pasal 21 yang akan dilampirkan yaitu perhitungan PPh Pasal 21 sesuai SPT Tahunan bagi 7 pegawai dengan status kawin TK/0 (belum kawin), K/1 (kawin dengan 1 orang anak), K/2 (Kawin dengan 2 orang anak), dan K3 (Kawin dengan 3 orang anak). Berikut ini adalah perhitungan PPh Pasal 21 dari sampel 7 pegawai kantor Kesyahbandaran dan Otoritas Pelabuhan Kelas 1 Bitung.

\subsubsection{Perhitungan PPh Pasal 21 Bagi Pegawai Tetap yang Menjadi Beban APBN}

Berdasarkan PMK 262 tahun 2010 pasal 9 atas penghasilan berupa honorarium atau imbalan lain dengan nama apapun yang menjadi beban APBN atau APBD dipotong PPh Pasal

21 dan bersifat final, tidak termasuk biaya perjalanan dinas. Tarif PPh Pasal 21 atas honorarium atau imbalan lain dengan nama apapun yang menjadi beban APBN atau APBD adalah sebagai berikut:

a. Sebesar 0\% (nol persen) dari penghasilan bruto bagi PNS Golongan 1 dan Golongan II, Anggota TNI dan Anggota POLRI Golongan Pangkat Tamtama dan Bintara, dan Pensiunannya. 
b. Sebesar 5\% (lima persen) dari penghasilan bruto bagi PNS Golongan III, Anggota TNI dan Anggota POLRI Golongan Pangkat Perwira Pertama, dan Pensiunannya.

c. Sebesar $15 \%$ (lima belas persen) dari penghasilan bruto bagi Pejabat Negara PNS Golongan IV, Anggota TNI dan Anggota POLRI Golongan Pangkat Perwira Menengah dan Perwira Tinggi dan Pensiunannya.

Berikut ini merupakan perhitungan $\mathrm{PPh}$ Pasal 21 atas honor :

4. Pejabat Pengadaan Barang/Jasa dan Panitia Pemeriksa/Penerima Pengadaan Barang/Jasa.

5. Pegawai Pelaksana Pengelolaan Sistem Akuntansi Pemerinntah Tingkat Wilayah, dan

6. Petugas Pengelola PNBP (Penerimaan Negara Bukan Pajak), Jasa Kenavigasian, Perkapalan dan Kepelabuhan.

\subsubsection{Pemotongan dan Penyetoran PPh Pasal 21}

Pemotongan $\mathrm{PPh}$ Pasal 21 pegawai Kantor Kesyhabandaran dan Otoritas Pelabuhan Kelas I Bitung dilakukan oleh KPPN dengan memotong langsung pajak penghasilan pasal 21 pada penghasilan pegawai masing-masing. PPh yang dipotong tersebut disetor ke Kantor Perbendaharaan Negara (KPN) Provinsi Sulawesi Utara yang kemudian akan disetor ke rekening Direktorat Jenderal Pajak.

\subsubsection{Pelaporan PPh Pasal 21}

SSPelektronik yang telah disetor kemudian akan dilaporkan oleh KPN di website Direktorat Jenderal Pajak dalam bentuk Comma Separated Value (CSV). CSV dibuat dengan cara sebagai berikut :

1. Log in pada aplikasi e-SPT dengan menggunakan NPWP dan password.

2. Membuat data baru sesuai bulan pajak terutang.

3. Mengisi data SPT yang didalamnya memuat data Daftar Pemotongan Pajak, SPT Induk dan Daftar SSP/Pbk.

4. Setelah semua data tersimpan, maka dibuat file CSV untuk dilaporkan melalui website

5. DJP online dan file PDF untuk dicetak dan diarsipkan.

Batas waktu pelaporan SPT PPh Pasal 21 yaitu tanggal 20 bulan berikutnya, menurut ketentuan undang-undang perpajakan. Setelah KPN membuat CSV SPT PPh Pasal 21 kemudian KPN melaporkan CSV tersebut pada website DJP online pada tanggal 20 bulan berikutnya,

\section{KESIMPULAN DAN SARAN}

\subsection{Kesimpulan}

1. Berdasarkan ketentuan Objek PPh Pasal 21 menurut PER-16/PJ/2016, masih terdapat objek PPh Pasal 21 yang belum dipungut oleh Kantor Kesyahbandaran dan Otoritas Pelabuhan Kelas 1 Bitung yaitu fee atas jasa servis AC, Komputer dan pemeliharaan gedung kantor dan gaji Cleaning Service.

2. Dari segi perhitungan Pajak Penghasilan Pasal 21 yang dilakukan oleh kantor Kesyahbandaran dan Otoritas Pelabuhan kelas 1 Bitung telah sesuai dengan aturan perundang-undangan perpajakan yakni Peraturan Direktur Jenderal Pajak Nomor PER-16/PJ/2016 untuk perhitungan PPh Pasal 21 bersifat tidak final dan berdasarkan PMK 262 tahun 2010 untuk perhitungan PPh Pasal 21 bagi pegawai tetap yang menjadi beban APBN.

3. Dari segi pelaporan SPT masa Kantor Kesyahbandaran dan Otoritas Pelabuhan kelas 1 Bitung dilakukan oleh Kantor Perbendaharaan Negara (KPN) melalui aplikasi $e$ filling pada website Direktorat Jenderal Pajak dan telah sesuai dengan ketentuan yang berlaku. 


\subsection{Saran}

Saran dari penelitian ini :

1. Merekrut pegawai yang cakap dan memahami tata cara perhitungan, pemotongan serta pelaporan PPh Pasal 21.

2. Sering menghadiri seminar-seminar perpajakan dan menggali informasi mengenai perpajakan khususnya menyangkut PPh Pasal 21.

3. Terus mengupdate sistem ataupun aplikasi penunjang dalam proses perhitungan sampai pelaporan SPT PPh Pasal 21

\section{DAFTAR PUSTAKA}

Afrisa Adhita Putri, 2016. "Perlakuan Akuntansi PPh Pasal 21 dan Pasal 25 terhadap Laporan Keuangan Koperasi”. Jurnal Ilmu dan Riset Akuntansi, Vol. 5, No. 5. ISSN 24600585 .

Allingham, Michael G., and Agnar Sandmo. "Income tax evasion: A theoretical analysis." Journal of public economics 1.3-4 (1972): 323-338.

Amelia Muaya, 2016. "Analisis Perhitungan, Penetapan dan Pelaporan Pajak Penghasilan Pasal 21 pada Yayasan Perguruan Tinggi Katolik Keuskupan Manado". Jurnal EMBA, Vol. 4, No. 2, Hal. 748-757. ISSN 2303-1174.

Angelia Friska Makabimbang, 2013. "Analisis Perhitungan, Pembayaran dan Pelaporan PPh Pasal 21 Pada Dinas Pendidikan Kecamatan Tuminting”. Jurnal EMBA, Vol. 1, No. 4, Hal 127-133. ISSN 2303-1174.

Arja Sudijarto, 2008. "Variasi Perhitungan dan Penyetoran Pajak Penghasilan Pasal 21 ". Jurnal Akuntansi dan Keuangan, Vol. 10, No. 1, Hal 48-68.

Dian Anggraini. "Analisis Perhitungan, Pemotongan, Pelaporan, dan Penyetoran Pajak Penghasilan (PPh) Pasal 21 atas Karyawan Tetap (Studi Kasus pada PT.

Sarah Ratu Samudera)".

Friedland, Nehemiah, Shlomo Maital, and Aryeh Rutenberg. "A simulation study of income tax evasion." Journal of public economics 10.1 (1978): 107-116.

Herduard R. Homenta, 2015. "Analisis Perhitungan, Pemotongan, Pencatatan, dan Pelaporan Pajak Penghasilan Pasal 21 pada CV. Multi Karya Utama". Jurnal EMBA, Vol. 3, No. 3, Hal 916-926. ISSN 2303-11.

Jeane Susan, 2013. "Analisis Perhitungan Pajak Penghasilan Pasal 21 pada PT. Megasurya Nusalestari Manado". Jurnal EMBA, Vol. 1, No. 4, Hal 1599-1607. ISSN 2303-1174.

Mangasi Sinurat, 2013. "Perhitungan dan Pemotongan Pajak (PPh) Pasal 21 atas Pegawai Tetap pada PT. PLN (Persero) Cabang Medan. Jurnal Ilmiah Accounting Changes”. Jurnal Ilmiah Accounting Changes. Vol. 01, No. $\quad 01 . \quad$ ISSN 2339-1723.

Meilany Kesek. "Prosedur Perhitungan dan Pelaporan Pajak Penghasilan (PPh) Pasal 21 Atas Gaji Pegawai Pada Pemerintah Kota Bitung".

Pissarides, Christopher A. "The Impact of Employment Tax Cuts on Unemployment and Wages; The Role ff Unemployment Benefits and Tax Structure." European Economic Review 42.1 (1998): 155-183. 